\title{
MUATAN PENDIDIKAN KARAKTER DALAM CERITA PENDEK DI BUKU PELAJARAN BAHASA INDONESIA SMA
}

\author{
Main Sufanti $^{1}$, Anis Oktaviani ${ }^{2}$, Jeni Nur Cahyati ${ }^{3}$, Khabib Sholeh ${ }^{4}$ \\ 1,2,3Universitas Muhammadiyah Surakarta \\ ${ }^{4}$ Universitas Muhammadiyah Purworejo \\ Email:ms258@ums.ac.id ${ }^{1}$, jenicahya548@gmail.com ${ }^{3}$
}

\begin{abstract}
Abstrak: Penelitian ini bertujuan untuk (1) Mendeskripsikan cerpen-cerpen yang dimuat di dalam buku pelajaran Bahasa Indonesia untuk SMA. (2) Mendeskripsikan muatan pendidikan karakter dalam cerpen-cerpen di buku pelajaran Bahasa Indonesia untuk SMA. Penelitian ini merupakan penelitian deskriptif kualitatif. Data dalam penelitian ini adalah kata, kalimat dan paragraf dalam cerpen-cerpen di buku pelajaran Bahasa Indonesia untuk SMA. Sumber data dalam penelitian ini adalah buku-buku pelajaran Bahasa Indonesia untuk SMA yang masih digunakan di SMA, baik berdasarkan Kurikulum 2006 maupun berdasarkan Kurikulum 2013. Teknik pengumpulan data yang digunakan dalam penelitian ini adalah teknik membaca dan mencatat secara intensif. Teknik analisis data dengan teknik heuristik dan hermeunitik. Hasil penelitian ini sebagai berikut. (1) Penelitian ini menemukan 18 buku pelajaran pada mata pelajaran Bahasa Indonesia, 3 buku tidak mencantumkan cerpen, dan 15 buku mencantumkan cerpen. Dalam 15 buku pelajaran ditemukan 27 judul cerita pendek. (2) Cerita-cerita pendek dalam buku pelajaran itu memuat potensi 12 nilai pendidikan karakter yaitu religius, tanggung jawab, peduli sosial, cinta damai, jujur, kerja keras, toleransi, semangat kebangsaan, cinta tanah air, bersahabat, demokrasi, dan rasa ingin tahu. Nilai pendidikan karakter yang paling sering muncul adalah religius, tanggung jawab, peduli sosial, dan cinta damai.
\end{abstract}

Kata Kunci: cerpen, buku, pendidikan, karakter.

\section{THE CONTENTS OF CHARACTER EDUCATION IN THE SHORT STORIES IN INDONESIAN HIGH SCHOOL TEXTBOOKS}

\begin{abstract}
This study aims to (1) Describe short stories published in Indonesian textbooks for high school. (2) Describe the content of character education in short stories in Indonesian textbooks for high school. This research is a qualitative descriptive study. Data in this study are words, sentences and paragraphs in short stories in Indonesian textbooks for high school. Data sources in this study are Indonesian language textbooks for high schools which are still used in high school, both based on the 2006 curriculum and based on the 2013 curriculum. Data collection techniques used in this study are intensive reading and recording techniques. Data analysis techniques with heuristic and hermeunitic techniques. The results of this study are as follows. (1) The study found 18 lessons in Indonesian language studies, 3 books that did not include a pen, and 15 books included a pen. In 15 lessons found 27 short stories. (2) Short stories in sufficient learning have the potential for 12 educational values of religious character, responsibility, social scrutiny, love, honesty, hard work, tolerance, nationalism, water love, friendship, democracy, and curiosity. The most frequently occurring educational values of character are religious, responsibility, social scrutiny, and love.
\end{abstract}

Keywords: short stories, books, education, character.

BASASTRA Jurnal Bahasa, Sastra, dan Pengajarannya

Volume 8 Nomor 2, Oktober 2020, P-ISSN 2302-6405, E-ISSN 2714-9765 


\section{PENDAHULUAN}

Dewasa ini pendidikan karakter perlu diselenggarakan, karena kualitas moral masyarakat Indonesia mulai meluntur. Hal ini membuktikan tidak tercapainya tujuan pendidikan nasional, yaitu mencetak peserta didik berpotensi serta memiliki kekuatan spiritual keagamaan, pengendalian diri, kepribadian, kecerdasan, akhlak mulia, serta keterampilan yang diperlukan dirinya, masyarakat, bangsa dan negara (Wulandari, 2016). Oleh karena itu, dibutuhkan kerangka teori pendidikan karakter yang didukung oleh filsafat moral, psikologi moral dan praktek pendidikan moral (Chowdhury, 2016).

Karakter adalah aspek perilaku, kepercayaan, perasaan, dan tindakan yang saling terkait (Rokhman, 2014). Nilai pendidikan karakter tidak dapat dipisahkan dalam setiap kegiatan pembelajaran. Pembelajaran sastra dapat dijadikan sebagai penunjang dalam penanaman pendidikan karakter pada peserta didik, karena pada dasarnya karya sastra merupakan cerminan kehidupan masyarakat yang mengandung nilai. Pembelajaran sastra akan berhasil jika guru dapat memilih bahan ajar secara tepat. Kriteria pengembangan bahan ajar yang berbasis pendidikan karakter antara lain: sesuai dengan kurikulum yang ditetapkan; wacana yang digunakan sesuai dengan latar belakang peserta didik; mengandung pesan yang dapat diambil peserta didik; mengandung unsur pendidikan serta moral (Azis, 2019).
Pembelajaran sastra merupakan salah satu pembelajaran dalam mata pelajaran Bahasa Indonesia. Salah satu materi dalam pembelajaran Bahasa Indonesia adalah apresiasi cerita pendek (cerpen). Cerpen merupakan jenis sastra Indonesia modern yang mempunyai fungsi dalam kehidupan, seperti menggambarkan lakon manusia, kepekaan sosial, dan kesejahteraan. Cerpen menyajikan suatu cerita yang menggambarkan suatu kehidupan manusia dengan indah.

Melalui pembelajaran apresiasi cerita pendek siswa dapat memahami cerita tersebut dan dapat mengambil manfaatnya, antara lain berupa nilainilai kehidupan.Cerita pendek adalah narasi singkat (kurang dari 10.000 kata) yang memiliki kesan tunggal yang dominan dan fokus pada satu karakter dalam satu situasi (Susanti, 2018). Cerpen yang mengandung nilai-nilai ini menjadi potensi yang bisa dikembangkan menjadi bahan ajar yang bermuatan nilai-nilai pendidikan karakter. Selain itu, cerita yang disajikan harus disesuaikan dengan tingkat siswa (Januari, 2018).

Salah satu bahan ajar apresiasi cerpen adalah buku pelajaran.Buku ini sering disebut dengan buku siswa atau buku teks. Pembelajaran apresiasi cerpen sering memanfaatkan bukubuku pelajaran Bahasa Indonesia. Pembelajaran bahasa Indonesia menggunakan pembelajaran berbasis teks (Siburian, 2020).Idealnya materi ajar yang terkandung dalam buku ini mengandung potensi muatan karakter 
yang dapat menginspirasi siswa memiliki karakter yang baik. Begitu pula, cerpen yang dimuat dalam buku ini idealnya juga berpotensi menjadi bahan ajar yang bermuatan pendidikan karakter. Ada beberapa macam nilai pendidikan versi kementerian Pendidikan dan Kebudayaan Indonesia tentang nilai-nilai pendidikan karakter yaitu yang bersumber dari agama, pancasila, budaya dan tujuan pendidikan nasional, yaitu (1) religius, (2) jujur, (3) toleransi, (4) disiplin, (5) kerja keras, (6) kreatif, (7) mandiri, (8) demokratis, (9) rasa ingin tahu, (10) semangat kebangsaan, (11) cinta tanah air, (12) menghargai prestasi, (13) bersahabat/komunikatif, (14) cinta damai, (15) gemar membaca, (16) peduli lingkungan, (17) peduli sosial, (18) tanggung jawab (Setiawan, 2019). Pendidikan karakter tidak bisa menjadi proyek sampingan; itu harus sepenuhnya diintegrasikan ke dalam kurikulum sekolah yang sedang berlangsung (Foster, 2016).

Berdasarkan alasan-alasan di atas, maka penelitian ini dilaksanakan untuk menganalisis muatan nilai karakter dalam cerpen-cerpen di buku pelajaran Bahasa Indonesia untuk SMA. Adapun tujuan secara rinci adalah: (1) mendeskripsikan cerpencerpen yang dimuat di dalam buku pelajaran Bahasa Indonesia untuk SMA dan (2) mendeskripsikan muatan pendidikan karakter dalam cerpencerpen di buku pelajaran Bahasa Indonesia untuk SMA.

\section{METODE}

Penelitian ini menerapkan penelitian kualitatif dengan pendekatan deskriptif. Metode penelitian kualitatif adalah suatu metode penelitian yang dilandaskan pada filsafat postpositivisme, digunakan untuk penelitian objek yang bersifat alamiah dengan peneliti sebagai instrumen kunci, purposive dilakukan dalam pengambilan sampel, triangulasi dalam teknik pengumpulan, analisis data bersifat indukti atau kualitatif, dan penekanan makna lebih diutamakan daripada generalisasi pada hasil penelitiannya (Sugiyono, 2009: $15)$.

Data yang diperlukan dalam penelitian ini berkaitan dengan pertanyaan dan tujuan penelitian, yaitu berupa kata, kalimat dan paragraf yang mengandung nilai pendidikan karakter dalam cerpen-cerpen di buku pelajaran Bahasa Indonesia untuk SMA. Sumber data dalam penelitian ini adalah bukubuku pelajaran Bahasa Indonesia untuk SMA yang masih digunakan di SMA, baik berdasarkan Kurikulum 2006 maupun berdasarkan Kurikulum 2013. Data-data tersebut dikumpulkan dengan teknik simak dan catat, yaitu teknik penyimakan pada suatu hal yang berhubungan dengan objek penelitian dan mengadakan pencatatan data yang relevan yang sesuai tujuan penelitian.

Teknik analisis data yang digunakan dalam penelitian ini adalah metode pembacaan model semiotik, yang terdiri atas pembacaan heuristik dan

pembacaan 
hermeneutik.Pembacaan heuristik merupakan pembacaan semiotik tingkat pertama berdasarkan konvensi bahasa. Sedangkan, pembacaan hermeneutik ialah memberikan interpretasi mengenai konvensi sastra (tingkat kedua). Jadi, karya sastra dapat dipahami berdasarkan muatan maknanya yang merupakan esensi sastra.

\section{HASIL DAN PEMBAHASAN}

Hasil penelitian ini meliputi paparan cerpen-cerpen yang dimuat di dalam buku pelajaran dan muatan nilai karakter dalam cerpen-cerpen tersebut.

\section{Cerpen yang Terdapat dalam Buku Pelajaran Bahasa Indonesia SMA}

Penelitian ini menemukan 18 buku pelajaran pada mata pelajaran Bahasa Indonesia yang digunakan oleh guru-guru di SMA di Surakarta. Bukubuku ini ditulis berdasarkan Kurikulum 2006 dan Kurikulum 2013. Berdasarkan pembacaan, dari 18 buku tersebut terdapat 15 buku yang mencantumkan bacaan berupa cerita pendek. Berdasarkan pembacaan yang cermat dari 15 buku ditemukan 27 judul cerita pendek. Berikut adalah daftar jumlah judul cerpen yang terdapat pada buku teks pelajaran bahasa Indonesia SMA.

Tabel 1: Judul Cerita Pendek

\begin{tabular}{cc}
\hline Buku Pelajaran & Jumlah Judul \\
\hline $\begin{array}{c}\text { Bahasa Indonesia } \\
\text { Kurikulum 2006 }\end{array}$ & 17 \\
\hline $\begin{array}{c}\text { Bahasa Indonesia } \\
\text { Kurikulum 2013 }\end{array}$ & 10 \\
\hline
\end{tabular}

Berdasarkan hasil analisis dapat dinyatakan bahwa terdapat 27 judul cerpen dalam 15 buku yang memuat cerita pendek berbasis pendidikan karakter. Buku Bahasa dan Sastra Indonesia untuk SMA/ MA Kelas XI Program Ilmu Alam dan Ilmu Sosial (2008) memuat tiga judul cerpen, yaitu Gak Tahu Malu, Prosesi, dan Duduk di Tepi Sungai. Buku Bahasa Indonesia SMA/ MA/ SMK/ MAK Kelas XI (Edisi Revisi 2017) memuat dua judul cerpen, Robohnya Surau Kami dan Matahari Terbit Pagi ini. Buku Berbahasa Indonesia dengan Efektif untuk Kelas XI Sekolah Menengah Atas/ Madrasah Aliyah Program Bahasa memuat cerpen Darmon. Buku Bahasa Indonesia SMA/ MA/ SMK/ MAK Kelas X (Edisi Revisi 2016) memuat cerpen Tukang Pijat Keliling. Buku Aktif dan Kreatif Berbahasa Indonesia untuk Kelas XI SMA/MA Program Bahasa memuat tiga judul cerpen Setrum, Sungai, dan Bertengkar Bebisik. Buku Belajar Efektif Bahasa Indonesia untuk Siswa SMA/MA kelas XI Ilmu Alam/ Ilmu Sosial memuat dua judul cerpen Di Atas Kereta Rel Listrik dan Jurdil. Buku Piawai Berbahasa Cakap Bersastra Indonesia untuk SMA/ MA Kelas XII Program IPA dan IPS juga memuat dua judul cerpen Dua Ratus Rupiah dan Pertemuan di Taman Hening. Buku Bahasa Indonesia Untuk SMA dan MA kelas XII (2010) memuat cerpen Perenungan Golda dan Ketika Surat Lamaranku Terbang. Buku Bahasa dan Sastra Indonesia 
Untuk SMA/MA kelas XII Program Bahasa (2008) memuat cerpen Lempengan-Lempengan Cahaya. Buku Bahasa dan Sastra Indonesia Untuk SMA/MA Kelas XII Program IPA/IPS (2008) memuat dua cerpen Bendera dan Maafin Nisa, Bi. Buku Bahasa Indonesia Untuk Sekolah Menengah Atas dan Madrasah Aliyah Program Bahasa (2009) memuat dua cerpen Dayu Komang dan Rumah untuk Kemenakan. Buku Aku Mampu Berbahasa dan Bersastra Indonesia Untuk SMA dan MA Kelas XII Bahasa (2010) memuat tiga cerpen Kembang Dewaretna, Cinta Tak Harus Memiliki, dan Lelaki yang Memberi Saya Uang. Buku Bahasa Indonesia Untuk Sekolah Menengah Atas dan Madrasah Aliyah Kelas XII Program Bahasa (2009) memuat cerpen Saksi Mata. Buku Aku Mampu Berbahasa dan Bersastra Indonesia Untuk SMA dan MA Kelas XII IPA/IPS (2010) memuat cerpen Salam dan Pesan Paman. Buku Bahasa Indonesia Untuk SMA dan MA Kelas XI Program IPA dan IPS (2010) memuat cerpen Gadis Pemulung Masuk Televisi.

\section{Muatan Pendidikan Karakter dalam Cerita Pendek}

Berdasarkan pengamatan pada lima belas buku teks pelajaran Bahasa Indonesia SMA, ditemukan dua belas bentuk pendidikan karakter. Dari dua belas wujud pendidikan karakter yang ditemukan, terdapat lima jenis pendidikan karakter dominan yaitu, religius, tanggung jawab, dan peduli sosial. Berikut akan disampaikan bentuk pendidikan karakter yang ditemukan dalam buku teks bahasa Indonesia SMA.

\section{Tabel 2: Nilai Karakter dalam Cerpen di Buku Pelajaran}

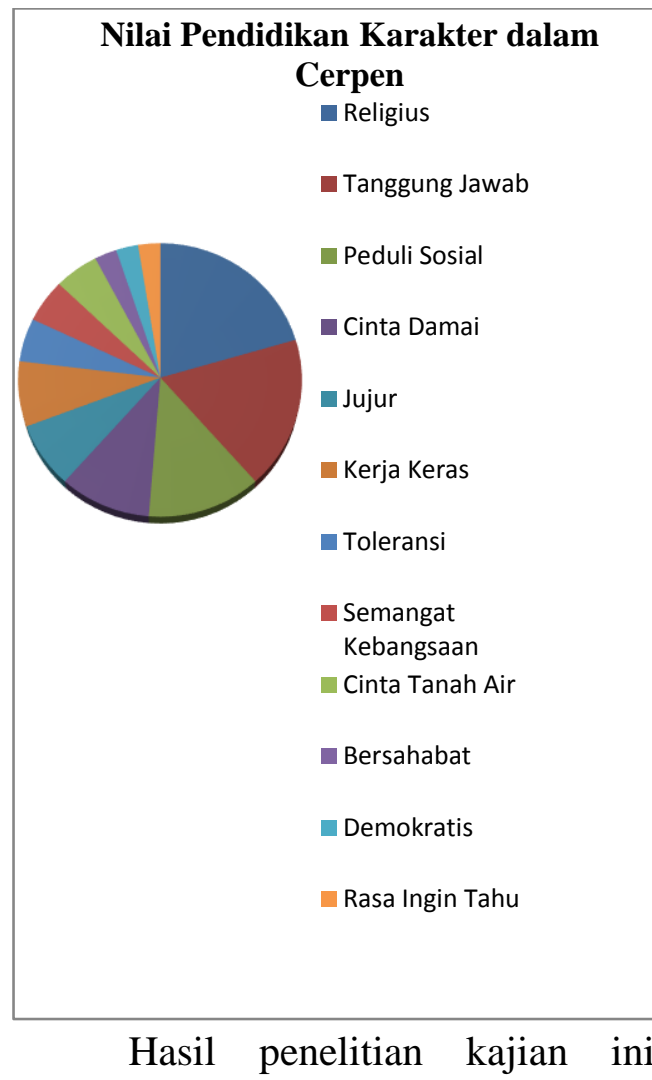

menunjukkan bahwa buku teks mata pelajaran bahasa Indonesia memuat bentuk nilai-nilai pendidikan karakter. Terdapat 12 bentuk nilai-nilai pendidikan karakter yang ditemukan dalam 27 judul cerpen yang ada pada buku bahasa Indonesia. Karakter religius ditemukan dalam 8 judul cerpen. Karakter tanggung jawab ditemukan dalam 7 judul cerpen. Peduli sosial ada di 5 judul cerpen. Nilai karakter jujur dan kerja keras 
ditemukan pada 3 judul cerpen. Nilai toleransi, semangat kebangsaan, dan cinta tanah air ada dalam 2 judul cerpen. Nilai karakter bersahbat, demokrasi, dan rasa ingin tahu, masing-masing aditemukan dalam 1 judul cerpen. Nilai pendidikan karakter ini tertuang dalam sebuah kalimat dalam paragraf. Muatan nilainilai pendidikan karakter dalam buku mata pelajaran bahasa Indonesia disampaikan secara implisit dan eksplisit dan disertai dengan contohcontoh penerapan nilai karakter dalam kehidupan sehari-hari.

Buku teks bahasa Indonesia SMA layak untuk digunakan oleh guru bahasa Indonesia karena memuat banyak pendidikan karakter yang dapat diteladani siswa. Buku-buku tersebut disesuaikan dengan kompetensi inti dan kompetensi dasar yang tercantum dalam silabus SMA. Kesesuaian cerpen-cerpen pada buku teks bahasa Indonesia sebagai bahan ajar pembelajaran sastra juga ditentukan dari isinya. Dalam cerpencerpen tersebut terdapat beberapa pendidikan karakter yang sesuai dengan kehidupan sehari-hari.

Pembahasan mengenai wujud unsur pendidikan karakter dalam buku teks pelajaran bahasa Indonesia dibagi menjadi lima kategori karakter berdasarkan nilai pendidikan karakter yang sering muncul dalam buku teks bahasa Indonesia. Penelitian Nurgiyantoro \& Efendi (2013) menunjukkan bahwa para guru SMP/MTs di DIY menyetujui sejumlah prioritas nilai yang mesti mendapatkan perhatian utama adalah nilai-nilai religius, jujur, cinta tanah air, peduli lingkungan, dan tanggung jawab, serta sejumlah nilai lain pada urutan berikutnya, yaitu nilai kreatif, gemar membaca, disiplin, dan mandiri. Daftar nilai yang dipilih untuk dibelajarkan juga sengaja diambil dari Kemendiknas (2010) yang disarankan untuk dibelajarkan di sekolah.Wujud nilai pendidikan karakter yang paling menonjol pada cerpen buku teks bahasa Indonesia adalah religius, pedulis sosal, peduli sosial, cinta damai, dan jujur. Berikut deskripsi wujud unsur pendidikan karakter dalam buku teks bahasa Indonesia SMA.

Berdasarkan hasil analisis dari lima belas buku teks ditemukan karakter yang paling sering ditemukan yaitu religius . Nilai ini dapat ditemukan di delapan cerpen, yaitu Prosesi, Duduk Di Tepi Sungai, Robohnya Surau Kami, Di Atas Kereta Rel Listrik, Lempengan Cahaya, Dayu Koman, Saksi Mata, Lelaki yang Memberi Saya Uang.

Religius adalah sikap dan perilaku yang patuh dalam melaksanakan ajaran agama yang dianutnya, toleran terhadap pelaksanaan ibadah agama lain, dan hidup rukun dengan pemeluk agama lain.

"Aku beranggapan jika kitab suci dapat mengajarkan hidup yang benar, pasti Bapak sudah menyuruhku mengaji."

"Zaman sekarang, belajar mengaji dianggap aneh. Bapak 
berpikir lebih baik aku belajar bahasa" (Sulastri, 2008: 135)

Nilai religius dalam cerpen ini digambarkan pada tokoh kakek. Kakek menceritakan mengenai keadaannya kepada cucunya, bahwa ia dulu tidak pernah sekolah. Melainkan dulu kakek belajar mengaji. Kakek menjelaskan bahwa mengaji dapat mengajarkan kita untuk berperilaku dan hidup yang benar. Sayangnya, pada zaman sekarang belajar mengaji dianggap aneh sehingga jarang diterapkan pada anak usia dini.

Nilai religius adalah nilai yang dapat mendekatkan kita kepada Tuhan yang Maha Esa. Sehingga kita tidak hanya memfokuskan nilai pendidikan di sekolah saja. Nilai religius harus diterpakan terlebih dahulu untuk menunjang pendidikan yang baik. Keberhasilan seseorang tidak hanya dari pendidikan sekolah saja, melainkan harus diseimbangi dengan ikhtiar.

Nilai karakter yang juga sering ditemukan dalam cerita adalah tanggung jawab. Tanggung jawab merupakan sikap dan perilaku seseorang untuk melaksanakan tugas dan kewajiban yang harus ia lakukan terhadap diri sendiri, masyarakat, lingkungan, negara, dan Tuhan Yang Mahaesa (Mamluah, 2017).

Nilai karakter tanggung jawab juga sering ditemukan dalam ceritacerita ini. Nilai karakter peduli ditemukan di 7 cerita pendek yaitu Prosesi, Setrum, Sungai, Pertemuan di Taman Hening, Maafin Nis, Bi, Salam
\& Pesan Paman, dan Gadis Pemulung Masuk Televisi.

"Saya meminta izin untuk membawanya, insya Allah aku yakin dia tidak akan menangis jika bersama saya. Bapak pun menyetuji dan memintaku berhati-hati. Kuucapkan terima kasih kepada beliau." (Somad, 2008: 152)

Sersan Kasim adalah sosok seorang ayah dan pemimpin yang tegas. Ia membawa anaknya sekaligus memimpin regunya dalam peperangan. Sersan Kasim telah memikirkan resiko yang akan ia hadapi jika semua tindakan tersebut tetap ia lakukan. Nilai yang diterapkan Sersan Kasim merupakan nilai pendidikan karakter tanggung jawab, diperjelas dengan pernyataan Meisusri dalam penelitiannya yang berjudul "Nilai pendidikan Karakter dalam Novel Malaikat-Malaikat Penolong Karya Abdulkarim Kharatuliah", nilai pendidikan tanggung jawab adalah berani mengambil resiko akibat perbuatan yang telah dilakukan , bersikap dewasa, dan kasih sayang orang tua kepada anaknya. Kasih sayang orang tua terlihat dari Sersan Kasim yang membawa anaknya saat peperangan, ia tidak ingin menitipkannya kepada warga sekitar, karena sebagai seorang ayah ia harus memberikan rasa sayang dan tanggung jawab yang besar untuk perkembangan anaknya.

Nilai karakter yang juga sering muncul di cerpen adalah peduli sosial. Nilai ini dimuat dalam 5 cerita yaitu, Robohnya Surau Kami, Tukang 
Pijat Keliling, Di Atas Kereta Rel Listrik, Dua Ratus Rupiah, dan Cinta Tak Harus Memiliki.

Nilai karakter ini ditemukan dalam karakter peduli adalah mau bekerja sama dan terlibat dalam berbagai kegiatan sosial yang ada di masyrakat. Menurut Wiyani (2012:95) peduli adalah sikap dan tindakan yang selalu berupaya mencegah kerusakan pada lingkungan di sekitarnya dan mengembangkan upaya-upaya untuk memperbaiki kerusakan lingkungan yang sudah terjadi, selalu ingin memberi bantuan kepada orang lain dan masyarakat yang membutuhkan.

"Orang-orang kampung mulai gelisah. Sudah dua malam kami tidak menjumpai Darko keliling kampung." (Suherli, 2016: 136)

Nilai pendidikan karakter peduli sosial diperankan oleh tokoh Darko. Darko hanyalah tukang pijat keliling yang keramahannya menambah daya pikat sendiri bagi pelanggannya. Ia selalu ramah kepada setiap orang, tanpa melihat derajat sosialnya.rasa kepedulian yang dimiliki Darko sangat tinggi. Diselasela pijatan yang dilakukannya, ia sering menceritakan hal-hal lucu di sehingga disegani oleh masyarakat. Darko dan masyarakat sekitar sangatlah akrab, suatu ketika Darko menghilang masyarakat gelisah.

Cerpen Tukang Pijat Keliling mengajarkan nilai peduli sosial. Dengan peduli terhadap sesama diharapkan dapat menghilangkan permusuhan.Watak tokoh Darko dapat kita terapkan di kehidupan sehari-hari karena orangnya yang ramah, menghormati, dan tak pernah membedakan masyarakat yang satu dengan yang lainnya sehingga menyebabkan orang lain merasa senang akan kehadirannya. Manusia sebagai makhluk sosial harus dapat bersosialisasi antara satu dengan lainnya karena kita membutuhkan orang lain dan orang lain membutuhkan kita.

Nilai karakter yang juga sering ditemukan dalam cerita adalah tanggung jawab.Tanggung jawab merupakan sikap dan perilaku seseorang untuk melaksanakan tugas dan kewajiban yang harus ia lakukan terhadap diri sendiri, masyarakat, lingkungan, negara, dan Tuhan Yang Mahaesa (Mamluah, 2017).

"Saya meminta izin untuk membawanya, insya Allah aku yakin dia tidak akan menangis jika bersama saya. Bapak pun menyetuji dan memintaku berhati-hati. Kuucapkan terima kasih kepada beliau." (Somad, 2008: 152)

Sersan Kasim adalah sosok seorang ayah dan pemimpin yang tegas. Ia membawa anaknya sekaligus memimpin regunya dalam peperangan. Sersan Kasim telah memikirkan resiko yang akan ia hadapi jika semua tindakan tersebut tetap ia lakukan. Nilai yang diterapkan Sersan Kasim merupakan nilai pendidikan karakter tanggung jawab, diperjelas dengan pernyataan Meisusri dalam penelitiannya yang berjudul "Nilai pendidikan Karakter dalam Novel 
Malaikat-Malaikat Penolong Karya Abdulkarim Kharatuliah", nilai pendidikan tanggung jawab adalah berani mengambil resiko akibat perbuatan yang telah dilakukan, bersikap dewasa, dan kasih sayang orang tua kepada anaknya. Kasih sayang orang tua terlihat dari Sersan Kasim yang membawa anaknya saat peperangan, ia tidak ingin menitipkannya kepada warga sekitar, karena sebagai seorang ayah ia harus memberikan rasa sayang dan tanggung jawab yang besar untuk perkembangan anaknya.

Nilai Karakter Cinta Damai juga sering ditemukan di dalam ceritacerita ini. Cerita yang memuat nilai karakter cinta damai adalah Matahari Tak Terbit Pagi Ini, Bendera, Dayu Koman, dan Perenungan Golda.

Cinta damai merupakan sikap, perkataan, dan tindakan yang menyebabkan orang lain merasa senang dan aman terhadap kehadirannya. Susanti dalam penelitiannya yang berjudul "Nilai Pendidikan Karakter dalam Novel Nazar-Nazar Jiwa Karya Budi Silistyo En-Nafi" memberikan dua contoh sikap yang mencerminkan cinta damai yakni memberikan nasehat pada orang lain dan membuat orang lain nyaman berada didekatnya.

"Aku mengatakan dengan

suara pelan kepada

Pangeran, bahwa aku tidak

akan pernah berubah."

(Suherli, 2017:132)

Nilai cinta damai dalam kutipan cerpen tersebut menceritakan mengenai perpisahan seseorang dengan orang yang disayanginya, sehingga membuat perasaannya menjadi sunyi dan hampa. Kenyamanan yang telah ia rasakan menimbulkan rindu yang tidak dapat dikatakan. Walau jarak memisahkan, kesetiaan akan selalu ia tanamkan.

Nilai kejujuran dimuat dalam cerita yang berjudul Gak Tahu Malu, Darmon, dan Perenungan Golda. Kejujuran merupakan dasar dari setiap usaha untuk menjadi lebih baik dan kuat secara moral. Dengan sikap jujur hal-hal buruk dapat dihindari. Tokoh wanita dalam cerpen tidak berkata jujur mengenai apa yang ia rasakan, sehingga ia berprasangka buruk kepada kakek yang duduk di sebelahnya. Setelah wanita itu tahu kebenarannya, ia menyesali perbuatannya. Berikut kutipannya.

"Dengan gelagat yang ditunjukkan pria itu, aku yakin bahwa kue yang kumakan ini adalah miliknya. Beliau sangat berbaik hati berbagi denganku. Aku menyesal telah berburuk sangka kepadanya." (Sulastri, 2008: 119)

Prasangka buruk merupakan sikap yang datang dari hati nurani manusia yang muncul karena hawa nafsu. Prasangka buruh salah satu sikap yang wajib kita hindari. Sikapjujurdan terbuka dapat kita terapkan untuk menghindari hal-hal buruk yang nantinya akan memperkeruh keadaan. Mamluah dalam penelitiannya berjudul "Nilai Pendidikan Karakter dalam Novel 
Bertokoh Dahlan Iskan dan Pemanfaatannya sebagai Bahan Ajar Teks Novel" menjelaskan bahwa kejujuran merupakan sikap yang erat kaitannya dengan hati nurani. Untuk menerapkan sikap ini manusia harus terus belajar untuk melawan hawa nafsu yang dapat menodai sikap jujur.lebih baik jujur dan bertanya mengenai hal yang membuat kita mencurigainya. Sikap seperti ini akan membuat ketidaknyamanan dalam bergaul khususnya dengan orang yang baru dikenal.

Nilai karakter Toleransi dapat ditemukan dalam cerita yang berjudul Bertengkar Berbisik dan Perenungan Gorda. Toleransi merupakan sifat atau sikap saling menghormati dan menghargai antarindividu atau antarkelompok dalam masyarakat. Sikap toleransi dapat menghindari terjadinya diskriminasi, walaupun terdapat golongan yang berbeda alam suatu kelompok masyarakat. Cara terbaik membangun toleransi adalah menumbuhkan semangat kesatuan yang dibangun di atas pilar kebangsaan (Sirait, 2014).

"Tokoh Aku menceritakan mengenai perbedaan kulitnya dengan temannya yang bernama Kasih.Ia berpendapat bahwa Kasih tidak terlalu menarik karena memiliki kulit yang gelap berbeda dengannya yang memiliki kulit putih seperti salju bahkan ia menyamakan kulit Kasih dengan kolam ikan koinya yang belum dibersihkan sebulan. Ia pun mengatakan bahwa Kasih memiliki wajah yang ndeso" (Suratna, 2010: 18-22).

Dari cerita tersebut kita mendapat pelajaran bahwa kita tidak boleh melihat orang lain hanya dari tampilan luar atau fisiknya saja. Kita harus menghargai adanya perbedaan karena perbedaanlah yang dapat menyatukan manusia. Jangan menilai orang lain sebelum kita mengenal secara mendalam orang tersebut. Bahkan jika kita sudah mengenal orang tersebut bukan berarti kita dapat menilai kejelekan orang tersebut. Apa yang kita ucapkan adalah cerminan diri kita.

Nilai Semangat Kebangsaan bias ditemukan dalam cerita Jurdil dan Saksi Mata. Nilai semangat kebangsaan adalah cara berpikir, bertindak, dan wawasan yang menempatkan kepentingan bangsa dan warga negara di atas kepentingan diri dan kelompoknya (Priyambodo, 2017). Nilai semangat kebangsaan harus dibiasakan supaya tercipta persatuan bangsa.

"Jurdil menulis surat yang kelima kepada kerabatnya yang ada di pesisir, bahwa dirinya (Jurdil) harus berhati-hati ketika berbicara di hadapan wartawan. Jurdil juga menuliskan sebelum dirinya berbicara di depan siapa pun, harus berkonsultasi terlih dahulu dengan ketua fraksi." (Kusnasi, 2009: 247)

Cerpen ini mengajarkan kita agar cara berfikir kita dapat diubah, bahwa tempatkanlah kepentingan bangsa dan negara di atas kepentingan 
kelompok. Sesuai dengan judul cerpen yakni Jurdil yang merupakan singkatan dari jujur dan adil. Jujurlah dalam berkata dan adilah dalam bertindak merupakan suatu sikap yang dapat mendorong negara kita lebih berkembang dan masyarakatnya lebih sejahtera. Janganlah mementingkan golongan hanya untuk mendapatkan simpati dari rakyat.

Nilai Cinta Tanah Air dapat ditemukan dalam cerita yang berjudul Rumah untuk Kemenakan dan Kembang Dewaretna. Cinta tanah air merupakan rasa kebangaan, rasa memiliki, menghargai, dan loyalitas tinggi yang dimiliki oleh setiap individu pada negara tempat tinggalnya. Cinta tanah air identik dengan sebutan nasionalisme. Secara ringkas, nasionalisme merupakan paham kebangsaan terhadap kesetian tertinggi individu terhadap bangsa dan tanah airnya (Ikhsan, 2017)

"Menurut kepercayaan warga setempat, lelaki yang sudah beristri akan pergi ke rumah yang baru. Dengan berat hati, Kalan meninggalkan rumah Ibunya yang sudah ia perbaiki dengan hasil kerja kerasnya. Semua ini dilakukan sebagai wujud penghormatan kepada budaya daerah." (Kusmayati, 2009:223-227).

Nilai Bersahabat ditemukan dalam cerita yang berjudul Bendera. Nilai bersahabat sering disebut dengan komunikatif. Nilai komunikatif merupakan

tindakan yang memperlihatkan rasa senang berbicara, bergaul, dan bekerja sama dengan orang lain (Wardani, 2018). Sikap ini disegani oleh setiap orang, karena mampu memberikan interaksi yang baik dalam bergaul.

"Ada dua gadis remaja yang didatangi oleh anak laki-laki lusuh yang ingin menyampaikan maksud hatinya untuk mengambil bendera yang dipasang dipinggir jalan yang nantinya akan dibuat celana namun kedua gadis yang tampak berasal dari keluarga kaya itu segera menyingkir karena merasa jijik dengan kehadiran sosok makhluk yang sangat mengganggu pemandangan itu" (Rohmadi, 2008: 70-73).

Dari tindakan kedua gadis tersebut dapat diambil sikap bahwa manusia tidak boleh saling membedabedakan. Pada saat bergaul kita tidak boleh melihat seseorang hanya dari tampilan luar atau dari status sosialnya saja karena itu akan menyakiti hati orang lain.

Nilai demokratis dimuat di dalam cerita yang berjudul Kembang Dewa Retna. Demokratis mengandung makna penghargaan terhadap harkat dan martabat manusia yang menyangkut hak dan kewajiban sebagai warga negara. Nilai demokratis yang dikembangkan dalam pembelajaran dimulai dengan menghargai perbedaan pendapat karena merupakan bagian dari demokrasi (Setiawan, 2017).

"Meskipun laki-laki tersebut tidak menyukai perannya 
sebagai Danapati tetapi ia tetap menerima peran tersebut dan ketika lawan perannya memberi pilihan untuk bertukar peran dengannya menjadi Rahwana, ia menolak karena setiap orang berhak untuk mendapatkan peran apa saja dan penonton yang akan menilai peran mereka" (Syamsi, 2010: 108-113).

Rasa ingin tahu bias ditemukan di Salam dan Pesan Paman. Rasa ingin tahu adalah cara berpikir, sikap dan perilaku yang mencerminkan penasaran dan keingintahuan terhadap segala hal yang dilihat, didengar, dan dipelajari secara lebih mendlaam (Kementerian Pendidikan Nasional, dalam Fauzi, 2017). Keingintahuan seorang siswa dapat dicirikan dengan seringnya bertanya dan mencari tahu tentang suatu hal yang sedang dihadapi.

"Paman Odik selalu bertanya kepada Rina mengenai kehidupan Rina. Bagaimana sekolahnya, berapa lama lagi ia akan sekolah, kapan ia menikah, dan bertanya mengenai laki-laki yang pernah mengisi hati Rina. Paman Odik bertindak demikian untuk mengetahui lebih dalam mengenai kehidupan Rina agar ia bisa membantu Rina jika ia mengalami masalah" (Syamsi, 2010: 15-19).

Rasa ingin tahu perlu ditanam dalam diri manusia tetapi kita harus mengetahui batasannya. Rasa ingin tahu akan membuat manusia menjadi lebih aktif dan akan memeliki banyak pengetahuan.

\section{SIMPULAN}

Simpulan penelitian ini sebagai berikut. (1) Penelitian ini menemukan 18 buku pelajaran pada mata pelajaran Bahasa Indonesia, 3 buku tidak mencantumkan cerpen, dan 15 buku mencantumkan cerpen. Dalam 15 buku pelajaran ditemukan 27 judul cerita pendek. (2) Cerita-cerita pendek dalam buku pelajaran itu memuat potensi 12 nilai pendidikan yaitu religius, tanggung jawab, peduli sosial, cinta damai, jujur, kerja keras, toleransi, semangat kebangsaan, cinta tanah air, bersahabat, demokrasi, dan rasa ingin tahu. Nilai pendidikan karakter yang paling sering muncul adalah religius, tanggung jawab, peduli sosial, dan cinta damai. Dengan demikian, cerpen yang terdapat dalam buku pelajaran Bahasa Indonesia SMA bisa dijadikan sebagai penanaman dan pengemabangan pendidikan karakter.

\section{REFERENSI}

Azis, M.A., Andayani, dan Suyitno. (2019). "Novel Sirkus Pohon Karya Andrea Hirata Sebagai Materi Ajar Sastra SMP: Sosiologi Sastra dan Nilai Pendidikan Karakter". BASASTRA Jurnal Bahasa, Sastra, dan Pengajarannya, 7 (2), 14-21.

Chowdhury, M. (2016). Emphasizing Morals, Values, Ethics, and Character Education in Science Education and Science Teaching. MOJES The 
Malaysian Online Journal of Educational Science, 4 (2), 2-16.

Fauzi, A.R. (2017). Penguatan Karakter Rasa Ingin Tahu dan Peduli Sosial Melalui Discovery Learning. JTP2IPS, 2 (2), 27-36.

Foster, A., A. Mattix dan Kimberley Daly. 2016. "Focus on Elementary: Creating Global Citizens: Using Attitudes and Action to Teach Character Education". Childhood Education, 92 (1), 80-85.

Ikhsan, M.A. (2017). Nilai-nilai Cinta Tanah Air dalam Perspektif AlQuran. Jurnal Ilmiah Pendidikan Pancasila dan Kewarganegaraan, 2 (2), 108114.

Januarty, R. dan Nima, H.N.A. (2018). Energizing Students' Reading Comprehension Through Multimodal Texts. International Journal of language Education, 2 (2), 14-22.

Kemendiknas. (2010). Panduan PendidikanKarakter di Sekolah Menengah Pertama. Jakarta: Kemendiknas.

Kusmayati, N.B. dan Trianingsih, E. (2009). Bahasa Indonesia Untuk Sekolah Menengah Atas dan Madrasah Aliyah Program Bahasa. Jakarta: Pusat Perbukuan, Departemen Pendidikan Nasional.

Kusnasi E. H., Purwoto, A., dan Aisah, S. (2009). Belajar Efektif Bahasa Indonesia untuk Siswa SMA/MA kelas XI Ilmu Alam/ Ilmu Sosial. Jakarta: Pusat Perbukuan, Departemen Pendidikan Nasional.

Mamluah, K. (2017). "Nilai Pendidikan Karakter dalam Novel Bertokoh Dahlan Iskan dan Pemanfaatannya sebagai
Bahan Ajar Teks Novel". Dialektika, 4 (1), 115-145.

Meisusri, S., Asri, Y., dan Ismail, M. (2012). Nilai Pendidikan Karakter dalam Novel MalaikatMalaikat Penolong Karya Abdulkarim Khiaratullah. Jurnal Pendidikan Bahasa dan Sastra Indonesia, 1 (1), 222- 229.

Nurgiyantoro, B. dan Anwar E. (2013). Prioritas Penentuan Nilai Pendidikan Karakter dalam Pembelajaran Sastra Remaja.Cakrawala Pendidikan, 32 (3), 382-393.

Priyambodo,

A.B.

(2017)

Implementasi Pendidikan

Karakter Semangat Kebangsaan dan Cinta Tanah Air pada Sekolah Berlatar Belakang Islam di Kota Pasuruan. Jurnal Sains Psikologi, 6 (1), 9-15.

Rohmadi, M. dan Kusumawati, Y. (2008). Bahasa dan Sastra Indonesia Untuk SMA/MA Kelas XII Program IPA/IPS. Jakarta: Pusat Perbukuan, Departemen Pendidikan Nasional.

Rokhman, F., Syaifudin, A., dan Yuliati. (2014). Character Education For Golden Generation 2045 (National Character Building for Indonesian Golden Years). Procedia - Social and Behavioral Sciences, 141, 11611165.

Setiawan, R. (2017). Pembangunan Nilai Demokrasi dan Nasionalisme sebagai Kurikulum Tersenyum di SMAN CMBBS. Jurnal Hermeneutika, 3 (1), 10-20.

Setiawan, A.R., Saddhono, K., dan Suhita, R. (2019). Analisis Psikologi Sastra dan Nilai 
Pendidikan Karakter Novel Laut Bercerita Karya Leila S. Chudori Serta Relevansinya Sebagai Bahan Ajar Apresiasi Sastra di SMA. BASASTRA Jurnal Bahasa, Sastra, dan Pengajarannya, 7 (1), 1-11.

Siburian, S, Hutagalung, S.M., dan Daulay, S. (2020). Development of Adobe Flash CS6 Learning Media in Short Story-Based on Learning Text of Advanced Local Community of Batak Toba Students in Tanjungmorawa. Budapest International Research and Critics in Linguistics and Education (BirLE) Journal, 3 (1): 591-599.

Sirait, Mutiara Octavia $\mathrm{Br}$, et al. 2014."Peran Forum Kerukunan Umat Beragam dalam Mengembangkan Nilai Toleransi di Kabupaten Bekasi".UJEC, 3 (2): 10-17.

Somad, Ali Abdul., Aminudin dan Yudi Irawan. (2008). Aktif dan Kreatif Berbahasa Indonesia untuk Kelas XI SMA/MA Program Bahasa. Jakarta: Buku Sekolah Eektronik (BSE).

Sugiyono. 2009. Metode Penelitian Kuantitatif, Kualitatif dan $R \& D$. Bandung: Alfabeta.

Suherli, Maman Suryaman, Aji Septiaji, Istiqomah. (2016). Bahasa Indonesia SMA/ MA/ SMK/ MAK Kelas X (Edisi Revisi 2016). Jakarta: Kementerian Pendidikan dan Kebudayaan.

Suherli, Suryaman, M., Septiaji, A., dan Istiqomah. (2017). Bahasa Indonesia SMA/ MA/ SMK/ MAK Kelas XI (Edisi Revisi 2017). Jakarta: Kementerian Pendidikan dan Kebudayaan.

Sulastri, E. dkk. (2008). Bahasa dan Sastra Indonesia untuk SMA/ MA
Kelas XI Program Ilmu Alam dan Ilmu Sosial. Jakarta: Pusat Perbukuan, Departemen Bahasa dan Sastra Indonesia.

Suratno dan Wahono. (2010). Bahasa Indonesia Untuk SMA dan MA kelas XII. Jakarta: Pusat Perbukuan, Kementerian Pendidikan Nasional.

Susanti, M., Hamidin, dan Ismail, M. (2013). Nilai-Nilai Pendidikan Karakter dalam Novel NazarNazar Jiwa Karya Budi Sulistyo En-Nafi. Jurnal Pendidikan Bahasa dan Sastra Indonesia, 1(2), 274-282.

Susanti, E, Juarni, dan Sobari, T. (2018). Application Of Ict Based Contextual Approach To Improve Writing Short Story Skill And Learning Interest Of Senior High School Students. JLER (Journal of Language Education Research), 1(3), 1623.

Syamsi, K. dan Efendi, A. (2010). Aku Mampu Berbahasa dan Bersastra Indonesia Untuk SMA dan MA Kelas XII Bahasa. Jakarta: Pusat Perbukuan, Kementerian Pendidikan Nasional.

Wardani, Y.F. dan Suhita, S. (2018). Nilai Pendidikan Karakter dalam Novel Rindu Karangan Tereliye: Tinjauan Psikologi Karakter. Jurnal Pendidikan Bahasa dan Sastra Indonesia, 2 (2), 246-274.

Wiyani, N.A. (2012). Manajemen Pendidikan Karakter; Konsep dan Implementasinya di Sekolah. Yogyakarta: PT Pustaka Insan Madani.

Wulandari, A., Kamaruddin, dan Sinaga, A. (2016). Nilai-Nilai Pendidikan Karakter dalam Cerpen dalam Buku Teks 
Bahasa Indonesia SMP Kelas

VII Terbitan Erlangga Tahun

2013. Pena, 6 (1), 20-34. 